\title{
COMMENTS ON WILL CONTESTS IN NEW YORK*
}

\author{
HENRY W. TAFT \\ New York Bar
}

Your committee first assigned to me the subject of Surrogate's Practice. I was appalled! To assume that I could speak with authority on that intricate subject revived a painful experience of thirty odd years ago when I became entangled in a maze of procedural complications. I had propounded two holographic codicils to the will of a wealthy American who had resided for many years in a foreign country. Without notice to the parties, the Surrogate made an order sending the matter to the Court of Common Pleas for trial. A motion there for a commission (the only way the necessary evidence could be obtained), was denied for want of power to issue a commission in a special proceeding. The Surrogate, who had the power in his court, refused to exercise it in a case pending in the Court of Common Pleas. The Court of Common Pleas declined for want of power to send the case back to the Surrogate's Court; and an application to the Surrogate for an order taking the case back to his court was also denied for want of jurisdiction. It was thus made impossible to prove the necessary facts; a discontinuance become necessary-and it was granted on a penalty of $\$ 350$ costs. Such are the perils which attend inarticulation of Code provisions. May the convention for procedural reform deliver us from them!

It may be imprudent. for me to advertise an ignorance of Surrogate's practice, but in a department of my office a knowledge of it is confidently professed. Indeed, I am so satisfied that some of my associates are experts that $I$ complacently concentrate upon matter's which require less of the skill of the chess player. This reminds me of an episode which survives among the traditions of my office.

My late senior partner, Mr. Cadwalader, was on one occasion expounding to a client, Dr. Billings, who was also an old and intimate friend, some quite intricate trust settlement, and followed a somewhat didactic explanation with the question, "Billings, do you understand?"; to which the Doctor (with some emphasis) replied, "No, and what's "more, I don't think that you do." Nothing daunted, Mr. Cadwalader rejoined, "Yes, that is true; but I have the advantage of you because "I have a young man in my office who does understand, and when he "explains it to me I understand it, and I don't think you're capable of "doing that." And so Dr. Billings, and perhaps Mr. Cadwalader, were

* Address delivered at a meeting of the Association of the Bar of the City of New York, on Janiary 13, Igar. 
left in ignorance, while the young man in the office solved the intricate problem;-and, we may hope, correctly.

And so I told your committee that I would make a few remarks on will contests. When I began to reflect, however, upon what might be expected, I was still disquieted, for one can wander, with little limit of space or time, into the numerous byways which diverge from the main road which leads to the probate or rejection of a will. But I shall confine myself to certain general comments which experience in the trial of such cases has suggested.

A person defined by the statute as being interested may object to the probate of a will. ${ }^{1}$ The question whether he is related to the testator in a degree qualifying him under the statute to object, may be preliminarily presented. Jurisdictional facts, such as the residence of the testator, may also be tried by the Surrogate in advance, or they may be reserved for consideration by him until after the main issue has been determined. Where the interests of public charities are involved, the Attorney General, representing the state, may become a party. By a statute of I886, the Surrogate has had the power in his discretion to transfer a probate proceeding to the Court of Common Pleas (and later to the Supreme Court), for trial by a jury. Since Igr4 a party has had the right to demand a jury trial where there is a controverted question of fact. ${ }^{2}$ Formerly, the executors of a propounded will found themselves in the embarrassing position of being compelled to defend an attack, and, if unsuccessful, personally to bear the expense of a contest. Now, however, the Surrogate may make a suitable allowance to cover such expense. ${ }^{3}$

Will contests may be based on a variety of grounds, such as the omission of the formalities of execution required by the statute, undue influence or fraud; lack of testamentary capacity, forgery, or revocation of the propounded instrument. The burden of proof rests upon the contestant except as to the factum and as to testamentary capacity.

Very slight proof is accepted by the courts to establish the fact that a will has been properly executed. Thus, in the case of the will of Homer A. Nelson, ${ }^{4}$ who in the early days of my practice was a state senator and a prominent member of the Poughkeepsie bar, the rule was laid down that if the attestation clause is shown to have been read and adopted by the testator, little additional proof of execution will be required. But the attestation clause of Senator Nelson's will omitted to recite that the testator had requested the witnesses to sign the will. and the only living subscribing witness denied that the testator had made such a request. A person superintending the execution of the will, however, had read the will in the testator's presence and had

${ }^{1} \mathrm{~N}$ Y, Code Civ. Proc., sec. $261 \%$ :

2 Id., sec. 2538.

Id., sec. 2746 .

-Matter of Nelson (I894) I4I N. Y. I52, 36 N. E. 3. 
requested the witness to sign, and this was held to be tantamount to a request on the part of the testator. This is a sensible ruling, for we all know that a bare request by a testator to the witnesses to act is adequate, without a literal compliance with some of the other rather mechanical requirements of the statute.

Under the procedure now generally adopted the proponent offers formal proof of execution and capacity, the contestant introduces evidence in support of his objections, and the proponent closes in rebuttal. In a jury trial special issues are framed upon motion before the Surrogate, and on the trial juries are instructed to find upon such of them as are submitted, and also to make a general finding. The Surrogate may determine not only the validity but also the construction and effect of a disposition of property, provided the question is suitably. presented, in the proceeding for the probate of the will. ${ }^{5}$ The Surrogate may dispose of such matters in that proceeding or may reserve them for future consideration. Frequently questions of construction. are reserved until the settlement of the executors' account, so as to avoid double proceedings.

Where fraud or undue influence is charged, much the same trial practice obtains as in actions for fraud at common law or in equity. A competent testator, subject only to provisions of the statutes relating to charitable bequests in a will, ${ }^{6}$ may leave his property to anyone he may select. He may cut off members of his family or any other person having a natural claim to his bounty. Injustice, ${ }^{7}$ capriciouness, ${ }^{8}$ and cruelty may be indulged in by a testator who is sane, and he may leave his property in such a manner as to be reprobated by all right-minded people, although such provisions may become an important element in proof of mental incapacity. Assistance in making his will may, of course, be sought, and few men omit to consult the members of their family and their legal advisers, and frequently their friends. Persuasion and even moral and intellectual pressure may be brought to bear, without becoming, within the meaning of the law, undue influence, unless it goes so far that the mind and the will of the persuader or the one exerting the pressure is substituted for the mind and the will of the testator. Even solicitation by an interested party, yielded to by a sane testator, is not undue influence. But influence may become undue when it is subtly exercised by one bearing a relation of trust to the testator. Where, for instance, a lawyer, a trustee, a confidential agent, or a guardian, or any other person occupying a fiduciary relation to a testator, availing of an advantage naturally incident to such relationship,

\footnotetext{
N. Y. Code Civ. Proc., sec. 2615.

'Decedent's Estate Law, sec. 17 (N. Y. Cons. Laws 1909, ch. I8).

${ }^{7}$ Dobie v. Armstrong (1899) 160 N. Y. 584, 55 N. E. 302; Horn v. Pullman (1878) 72 N. Y. 269; Shayne v. Shayne (1907, Sup. Ct.) 54 Misc. 474, 479, 106 N. Y. Supp. 34, 37.

'Children's Aid Society v. Loveridge (1877) 70 N. Y. 387.
} 
succeeds in inducing a testator to make a provision in his favor, the transaction will be rigidly scrutinized. Weakness of mind, not amounting to actual incapacity, is also sometimes an important element. Influence exercised upon a sane testator who is old and weak, but lacks the will power to resist a stronger will than his own, may be undue, although it would not be a valid ground of objection if attempted upon a mind having greater power of resistance. But age and mental and physical weakness alone do not incapacitate a person from making a will. Even the natural failure of the memory due to age, is not necessarily a disqualification.

The courts have dealt with the subjcet of testamentary capacity in an intensely practical way. They have attached primary importance to the capacity of a testator to manage his own affairs. ${ }^{\circ}$ They consider his education, his environment, and his character, and they compare him when he made his will with his normal self. ${ }^{10}$ They are inclined to dismiss abnormal eccentricities, ${ }^{12}$ failure of memory, ${ }^{12}$ perversities of temper, ${ }^{13}$ and even actual delusions, ${ }^{14}$ if affirmative evidence points to capacity. But if such abnormalities have a causative relation to the act of testamentation, or if there is some clearly unjust discrimination, especially if it is connected with a mental deficiency such as a fixed and unalterable delusion concerning a relative of the testator having a claim to his bounty, it may outweigh positive evidence of capacity.

Unusual and unconventional testamentary provisions are dangerous experiments, especially if there is a background of eccentricity or perversity of character; for they invite contests and may make expedient a settlement defeating the manifest design of the will. Testators will be well-advised if they refrain from giving vent to their feelings by expressing bitterness or prejudice, or even views contrary to the ordinary current of men's thoughts. The danger from this source has been enhanced since the issue of competency has been submitted to juries.

\footnotetext{
'Horn v. Pullman, supra; Pettit v. Pettit (1912) 149 App. Div. 485, 490-491, I34 N. Y. Supp. I33, 137; Matter of Heaton (I918) 224 N. Y. 22, 28, 120 N. E. 83, 85; Ivison v. Ivison (Ig03) 80 App. Div. 599,602, 80 N. Y. Supp. IorI, ror3; Matter of Murphy (I899) 4I App. Div. I53, 50 N. Y. Supp. 450; Chandler $v$. Fisher (1919) 290 Ill. 440, 446, 125 N. E. 324, 326.

${ }^{10}$ Mudway v. Croft (1843, Prerog. Ct. Canterbury) 2 Thorn. Notes, 438, 443.

"Ivison v. Ivison, supra.

"Van Guysling v. Van Kuren (I866) 35 N. Y. 70; Matter of Heaton, supra note 9; Matter of Barney (rgig) I85 App. Div. 782, I74 N. Y. Supp. 242; Clapp v. Fullerton (I866) 34 N. Y. I90; Pilling v. Pilling (I865, N. Y. Sup. Ct.) 45
Barb. 86; Pettit v. Pettit, supra note 9.

${ }^{13}$ Matter of Murphy, supra note 9.

"Van Guysling v. Van Kuren, supra; Clapp v. Fullerton, supra; Matter of Will of White (1890) 121 N. Y. 406, 24 N. E. 935; Dobie v. Armstrong, supra note 7; Coit $v$. Patchen (I879) 77 N. Y. 533; Burke v. Burke (I920, N. Y.) 193 App. Div. 80r; Middleditch v. Williams (I889, Prerog. Ct.) 45 N. J. Eq. 726, 733 , I7 Atl. 826, 829, reversed on other grounds in (1890) 47 N. J. Eq. 585. 21
Atl. 290 .
} 
I wonder how the will of Lewis Morris, a Yale man, dated November I9, I760, would have fared with a New York jury. He expressed the desire that his. son Gouverneur should have the best education to be had in England or America, but expressly directed that he

"be never sent for that purpose to the colony of Connecticut, lest he should imbibe in his youth that low craft and cunning so incident to the people of that country, which is so interwoven in its constitution that all their art cannot disguise it from the world, tho many of them, under the sanctified garb of religion, have endeavored to impose themselves on the world for honest men."

Probably the will of his descendant, Gouverneur Morris, dated October 6 , 1816, would not have excited less wonderment. He confirmed an ante-nuptial agreement giving his wife an annuity and provided that in case she should remarry she was to receive a further annuity of $\$ 600$ "to defray the increased expenditure which may attend that connection." Even satire or thinly veiled bitterness is not without its dangers, as in the case of the French lawyer who left a large amount to a lunatic asylum, declaring that many of his clients who paid him should have been inmates; or the case of an old bachelor who left all his property to old ladies who had refused his offers of marriage, stating that he had made the gift because "to them I owe all my earthly happiness."

A will ought to be an instrument for serious expression of testamentary intention, and not the vehicle for the expression of irrelevant and peculiar views, however honestly held. Otherwise the testator creates evidence which may tend to defeat his own purposes.

The courts do not strain for probate. While the burden rests upon the proponent to prove testamentary capacity, yet very slight evidence from the subscribing witnesses will put a contestant to his proof, after which the proponent proceeds in rebuttal, or, practically speaking, in defense. It is almost a fiction to say that the burden rests upon the proponent, or rather it is an illustration of the nuance,-the subtle, metaphysical shading given by the courts to the expression" "burden of proof," which is the despair of the ordinary juryman, if, indeed he attempts to grasp it at all. To all intents and purposes, upon the question of testamentary capacity, the contestant has the laboring oar, even though nominally the burden of proof does not rest upon him.

The decision in Delafield $v$. Parish ${ }^{15}$ has done much to cause litigation, particularly since the question of testamentary capacity has been tried before juries. Judge Davies, in a very lengthy opinion in that case, said:

"We have held that it is essential that the testator has sufficient capacity to comprehend perfectly the condition of his property, his relations to the persons who were, or should, or might have been the objects of his bounty, and the scope and bearing of the provisions of his will. He must, in the language of the cases, have sufficient active

${ }^{25}$ (1862) 25 N. Y. 9. 
memory to collect in his mind, without prompting, the particulars or elements of the business to be transacted, and to hold them in his mind a sufficient length of time to perceive at least their obvious relations to each other, and be able to form some rational judgment in relation to them" (p. 29).

If these words were given their strictly literal meaning they would constitute a wholly impracticable test. To "comprehend perfectly" would require a testator to know every detail of his possessions, and the richer he was, the greater would be the danger that he would fall below the standard of competency. Few millionaires could stand the test. For how could they master the fluctuating state of their diversified investments or the puzzling complications, legal and otherwise, of their business affairs? The courts, particularly the appellate courts, in practice have ignored the words of Judge Davies and have measured the comprehension of a testator by the varying mental capacity of the experienced and the inexperienced, the stupid and the clear-headed, the careless and the meticulous, the bold and the cautious, the conscientious and the indifferent.

What a perfect comprehension by a testator of "his relations to the "persons who were or should or might have been the objects of his "bounty," may be, is difficult to define, but, practically, the courts have interpreted this language of Judge Davies not in its literal sense, but as connoting the relations to persons who would, by reason of kinship or similar relationship, be regarded ordinarily as proper persons for the benefactions of a testator.

Again Judge Davies says that a person must have

"sufficient active memory to collect in his mind, without prompting, the particulars or elements of the business to be transacted, and to hold them in his mind a sufficient length of time to perceive at least their obvious relations to each other and be able to form some rational judgment in relation to them."

If we were to interpret these words according to their literal meaning, it would be impossible for a forgetful old man to make a will, where he had depended for information upon memoranda, or had had his memory stimulated by persons in charge of his property.

With respect, I submit to trial judges, that it would be better to avoid quoting the generalizations of Judge Davies, to the inevitable confusion of juries, and to base their charges on the later decisions which have practically ignored them as a guide. In only one case that I have discovered have the appellate courts had the boldness to give a hint to this' effect. That was in Matter of Barney, ${ }^{16}$ where the Appellate Division in this department said that the Court of Appeals in the Delafield Case "was merely considering the sufficiency of the evidence "on the trial of the issue before the Surrogate and was not laying down "a rule for the instruction of jurors."

\footnotetext{
${ }^{16}$ Supra note I2.
} 
But while the rule in Delafield $v$. Parish, if applied literally, would result in the rejection of many wills, it rarely happens that probate is finally refused by an appellate court. In this department ${ }^{17}$ an extensive search since I886 has disclosed only four cases (in I889, ${ }^{18}$ $1893,{ }^{18}$. $1917,,^{20}$ and $1920^{21}$ ) where verdicts of a jury against a will, on the ground of want of testamentary capacity, have been sustained on appeal. But will contests based on that ground seem to have increased in number since jury trials became in IgI4 a matter of right. It has not been practicable to procure the statistics throughout the state, but in this county $^{22}$ in fifteen cases testators have been found by juries to be without testamentary capacity. $U_{p}$ to date three verdicts to that effect have been sustained on appeal. In two cases the verdicts were acquiesced in, in two they were set aside by the Surrogate, and in two by the appellate courts, while three cases were settled. Appeals or motions are pending in five cases. ${ }^{23}$ The fifteen cases occupied 190 days or nearly one entire court year. ${ }^{24}$

The tendency in other jurisdictions is not without interest in this connection.

In a very interesting book written by Robert Grant, who for many years has been a Probate Judge in Boston, entitled Law and the Family, he speaks of the popular impression that the intention of testators is easily frustrated, but adds that in spite of the numerous attacks of "disappointed or greedy relatives," the records of the largest county of the state of Massachusetts, "where predatory tendencies against testa"tors are well developed," show

"a steady average of rather less than $\mathrm{x} \%$ of wills disallowed during the last ten years, a result which is made more remarkable by the reminder that some of these were set aside because of defective attestation instead of the mental incapacity and undue influence of the maker, ordinarily urged by the rapacious. The statistics for the same period show a yearly average of less than I\% of wills compromised-that is, where the legatees and next of kin agreed to split their differences with the sanction of the court. . .

"It is rather surprising, however, that the showing on the side of validity should be so good considering the haphazard and hasty, if not sloppy, execution of so many wills."

As an instance of this reference a digression will be excused to quote Judge Grant's reference to the

${ }^{27}$ Appellate Division of the Supreme Court, First Department.

${ }^{18}$ Matter of Bull (I889) III N. Y. 624, Ig N. E. 503.

${ }^{19}$ In re Gannon's Will (1893, N. Y. C. P.) 2 Misc. 329, 2I N. Y. Supp. 960.

${ }^{20}$ Matter of Emilie Schmidt (I9I7) I80 App. Div. 927, I67 N. Y. Supp. I 126.

${ }^{21}$ Matter of Jane E. Barney (1920, App. Div.) I83 N. Y. Supp. 944, (I920, App.

Div.) 184 N. Y. Supp. 907.

${ }^{22}$ County of New York.

${ }^{23}$ Minute Books, Trial Term Clerk, Surrogates' Court, New York County.

"Ibid. 
"fatal habit of altering wills after execution, indulged in especially by old ladies, who are fond of tucking into the vacant spaces left by incautious scriveners or inserting between the lines, the various changes and after-thoughts concerning their possessions which occur to them. Nothing is more dangerous than tampering with one's will and nothing more uncertain in its consequences; the law reports abound in cases which show results utterly at variance with the intentions of the tamperer, yet democracy is prone to ask pathetically and with some surface show of reason: Must we send for a lawyer and have the will re-executed every time we wish to make a change, when it would seem so simple to scratch out 'Jane' and substitute 'Emily' in case we are out of conceit with Jane?"

A jury trial in a contest based on fraud, undue influence or forgery, is appropriate and satisfactory, because the issue is generally simple. Where the issue is testamentary capacity, however, the contest stands upon a different footing. It is more than doubtful whether jurors are so equipped by experience, or can on an occasional trial be so instructed, as to enable them to understand the subtleties of the law, or whether they can be depended upon to resist the temptation to dispose of a testator's property, not in accordance with the provisions of his will, but rather in consonance with their own ideas of a suitable distribution. If there were any compensating advantages from a jury trial it might have some utility, but unless the Appellate Division is deprived of its powers to review the facts, a jury trial is chiefly useful in enabling contestants to avail of the complication and expense of protracted litigation to force settlements defeating the wishes of testators-often competent ones; for, as I have said, it rarely happens that a verdict finding an absence of testamentary capacity is sustained on appeal. The capacity of a testator to attend to his daily affairs in a normal way is accepted by the higher courts as showing testamentary capacity, in spite of evidence of eccentricities, perversities, and even delusions, and against the uncontradicted evidence of expert witnesses. Thus, forgetfulness of recent events, ${ }^{25}$ persistent delusions of witches and spooks, ${ }^{26}$ unfounded suspicion of a wife's infidelity and the legitimacy of a child, ${ }^{2 \pi}$ the use of irrational language at night concerning a conspiracy and the imagined hearing of vocies, ${ }^{28}$ the delusions of a testatrix of a sexual type influencing her daily existence and leading her to think that men were in love with her, ${ }^{29}$ the belief that there was "something in me, something "strange," wife "in the air looking like an angel," 32 the undue suspicion of the hon-

${ }^{25}$ See note 12 , supra.

"Van Guysling v. Van Kuren, supra note I2.

${ }^{\pi}$ Clapp v. Fullerton, supra note $\mathrm{i} 2$.

${ }^{23}$ Children's Aid Society v. Loveridge, supra note 8.

- Matter of Heaton, supra note 9.

${ }^{30} \mathrm{Ibid}$.

"Ivison v. Ivison, supra note 9.

${ }^{2} \mathrm{Ibid}$. 
esty of people and the excessive fear of impoverishment, ${ }^{33}$ indecency and degeneracy, ${ }^{34}$ fancied intrusions, ${ }^{35}$ and the state of being capricious; whimsical, and full of prejudice $;^{36}$-such things as these have been regarded by the higher courts as not outweighing affirmative evidence showing capacity to do business and to attend to ordinary affairs.

Then too, the testimony of medical experts, so common in gontested will cases, based upon hypothetical questions, is dismissed as not of a character to create an issue for a jury. In two cases in the Third Department, the Appellate Division set aside a verdict against wills based upon such evidence, and not only that, but ordered the wills tc be admitted to probate; and this was done for the expressed reason that the issues should never have been allowed to go to the jury solely upon the testimony of expert witnesses. ${ }^{37}$ In a case which I tried within a few years, three of the most eminent alienists in this city had testified that the testator, who had suffered from a stroke of apoplexy indicating a lesion of the brain and had committed suicide, was incompetent to execute a will. The Surrogate directed a verdict in favor of the proponents at the close of the contestant's case, and his ruling was unanimously sustained by the Appellate Division, without opinion. ${ }^{88}$ A motion made for leave to go to the Court of Appeals was denied with this significant memorandum per curiam, that

"if the Court of Appeals does not consider the law settled by its numerous decisions on the question of the 'degree of proof required to carry an issue of fact to the jury' application can be made to it to permit an appeal in this matter. We are satisfied that our decision was within the limits of their decision."

The question of the sufficiency of proof to carry the case to the jury was thus, with a faint trace of judicial defiance, raised. The Court of. Appeals did grant leave to appeal, but after argument affirmed the judgment, ${ }^{39}$ thus in effect deciding that the uncontradicted testimony of three eminent medical experts as to testamentary capacity, did not rise to the dignity of evidence creating a conflict requiring submission to a jury.

This phase of will contests would not be complete without considering the power of the Appellate Division to deal with facts. That court hears a will contest practically as if it were trying the case anew. It renders a decision upon the facts, irrespective of the findings of a jury,

${ }^{33}$ Matter of Barney, supra note I2; Matter of Will of White, supra note I4.

${ }^{34}$ Matter of Skaats (I893, N. Y. Sup. Ct.) 74 Hun, 462, 26 N. Y. Supp. 494; Estate of Smith (1915) $250 \mathrm{~Pa} .67,95$ Atl. 338.

${ }^{23}$ Burke v. Burke, supra note 14 ; Shreiner v. Shreiner (1896) 178 Pa. 57, 35

Atl. 974; Huffnagle v. Pauley (1920, Mo.) 219 S. W. 373.

${ }^{3}$ Children's Aid Society v. Loveridge, supra note 8.

${ }^{37}$ Matter of Dunn (1918) I84 App. Div. 386, 171 N. Y. Supp. 1056; Matter of Brand (1918) 185 App. Div. 134, I73 N. Y. Supp. I69.

${ }^{3}$ Matter of Kennedy (1919) 190 App. Div. 896, 178 N. Y. Supp. 897.

* (1920) 229 N. Y. 567. 
precisely as Surrogates always did before jury trials were in vogue. Its power is inherent and is confirmed by express provisions of the Code.

Originally, the governor of the province, by grant of the Crown, had probate jurisdiction. At an early day in our colonial history the jurisdiction became vested in courts of probate, and then in the Court of Chancery, to whose powers and jurisdiction the present Supreme Court succeeded. The best view seems to be that that court now possesses probate jurisdiction as the Ordinary. ${ }^{10}$ Its power as the prerogative court of original jurisdiction was confirmed to it by the Constitution and embraces the entire scope of the probate juirisdiction of the old ecclesiastical courts. That being so it has power to rehear the case at large. If it chose to do so, it might take evidence and proceed as in a rehearing in equity. ${ }^{41}$ Without specific reference to its historical origin, section I3I7 of the Code of Civil Procedure affords a statutory basis for the exercise of this broad power, for it provides that the Appellate Division "may reverse or affirm, wholly or partly, "or may modify the judgment or order appealed from" and may

"render judgment of affirmance, judgment of reversal and final judgment upon the right of any or all of the parties, or judgment of modification thereon, according to the law, except where it may be necessary or proper to grant a new trial or hearing when it may grant a new trial or hearing."

With more specific reference to the ancient probate power of the Supreme Court, section 2763 of the Code provides that where an appeal is taken on the facts,

"the appellate court has the same power to decide the questions of fact which the Surrogate had; and it may in its discretion receive further testimony or documentary evidence and appoint a referee."

As the trial by jury is not a constitutional right, the provision of the Code vesting in the Appellate Division original jurisdiction to grant a remedy, does not infringe upon that instrument. There have been cases, as I have already pointed out, where the Appellate Division upon reversing the decree of the Surrogate denying probate after a jury trial, have directed affirmatively that the wills be admitted to probate.

But in spite of the practically unlimited power of the Appellate Divi-

${ }^{+0}$ Matter of Brick (1862, N. Y. Surro.) I5 Abb. Pr. 12; Matter of Martin (Igr3, Surro.) 80 Misc. I7, I4I N. Y. Supp. 784; Vanderbeyden v. Reid (1826, N. Y.) Hop. Ch. 464.

"See Baylies, New Trials and Appeals (2d ed.) II5; Matter of Gaines (1895, N. Y. Sup. Ct.) 84 Hun, 520, 32 N. Y. Supp. 398; Burger v. Burger (I888) III N.·Y. 523, I9 N. E. 99 ; Clapp v. Fullerton, supra note 12; Matter of Warner (1900) 53 App. Div. 565, 65 N. Y. Supp. I022; Matter of Spondre (1917, Surro.) 98 Misc. 524, 162 N. Y. Supp. 943; Matter of Weed (IgII) 143 App. Div. 822, I27 N. Y. Supp. 966; Matter of Rice (19a3) 8I App. Div. 223, 8I N. Y. Supp. 868. 
sion to deal with the facts, an increase in the number of will contests has undoubtedly been caused by the hope of contestants that results can be obtained from juries which could not have been expected from Surrogates, and that even if verdicts are not sustained by the Appellate Division, at least they may result in a compromise.

In a case tried by the Surrogate of New York County several years ago, probate was refused on the ground of lack of testamentary capacity and of undue influence. ${ }^{42}$ On appeal the decree was reversed ${ }^{43}$ and $I$ tried the case for the contestant in the Supreme Court before a jury. The court withdrew the issue of undue influence, and a verdict was rendered against the will on the ground of lack of testamentary capacity. This verdict was set aside and a new trial ordered. The contestant could have gone back for a new trial or appealed from the order setting aside the verdict. But the proof was such that the Appellate Division would probably have affirmed the order and a new trial would have resulted, unless an appeal had been taken to the Court of Appeals. Perhaps the case might have ended by the decision of the Court of Appeals, but if we had elected to take a new trial, and there had been the same result, we would have been on our way a third time through the Appellate Division to the Court of Appeals. A vista of unending litigation was thus opened up and everybody finally agreed that the best thing to do was to settle the case; and that we did, substantially defeating in many material respects the wishes of the testatrix as expressed in her will.

The very nature of will contests involving testamentary capacity is such that they require an investigation of the entire life history of the testator, and that protracts tne many weeks. I believe the Eno trial occupied more than three months; and a case I tried before Surrogate Cohalan and a jury last spring extended through more than six weeks. The cost of such trials to both the state and decedents' estates is enormous.

An address on will contests would be incomplete without some observations upon the rules of evidence especially affecting them, and first I deal with medical expent testimony already alluded to.

The process of eliciting from medical experts answers to hypothetical questions concerning mental capacity, has come to be a highly artificial and a wholly unconvincing performance. Both juries and the courts largely ignore such evidence, seeking as a basis for their deductions evidence showing objectively capacity of a testator to attend intelligently to his current affairs. The refinements of the medical science applied as they are to facts postulated in an interminable question prepared by counsel, interest them chiefly as intellectual gymnastics. They usually dismiss the learned medical disquisitions with ill-concealed amusement. Many years ago Surrogate Rollins said that an expert physician was

2 Matter of Cutter (I9r5, Surro.) 89 Misc. 663, I54 N. Y. Supp. 250.

${ }^{*}$ Matter of Cutter (Igr6) I75 App. Div. 647, 162 N. Y. Supp. 545. 
called as a witness because his pre-ascertained views met the necessities of one of the litigants; and he added that the gist of the question propounded to them to establish insanity was "if the person whose "mental condition is the subject of inquiry is of unsound mind, is he "sane or is he insane?"; and that on the other hand, on cross-examination the question asked by opposing counsel resolved itself into the interrogatory. "But if on the contrary this person of whom you are testi"fying is of sound mind, is he insane or is he sane?" "Th "Th is now substantially the view of courts. Thus the Appellate Division has held that "the proof of experts based upon a hypothetical question in opposi"tion to proof showing . . . intelligence, scarcely, if at all, raised an "issue for the jury;" and the Court of Appeals in effect has held, as we have already said, ${ }^{48}$ that the uncontradicted evidence of three medical experts does not constitute a scintilla of proof requiring the submission of a case to a jury.

And so this kind of evidence has become an excrescence upon our court procedure. This situation ought to be of serious moment to the medical profession, which may well consider whether its dignity and usefulness is not being impaired by the slight respect paid to views asserted to be based on established principles of the medical science. The juridical method by which courts seek to determine whether a man is competent to make a will is quite different from the theoretical process of the medical expert witness. It resembles more the process which alienists themselves adopt in examining a living patient; for they rely upon concrete objective symptoms ascertained by tests which experience teaches them to apply. In other words, they have a process corresponding to cross-examination, by which they seek to ascertain truth. But medical men, testifying as expert witnesses, make deductions from assumptions embodied in hypothetical questions, being asked to accept statements of lay witnesses as to symptoms which in their day to day practice they would not think of accepting without subjecting them to the tests referred to. It is impossible for the medical profession by theoretical expositions to change the judicial process of investigation. It is too firmly embedded in our jurisprudence. Furthermore, while it is not infallible, scientifically it is subject to less weighty objections than an investigation based on the artificial hypothetical question process. But whether that is so or not, it is certain that the conflict between the two methods is ineradicable; and the unfortunate condition remains that by the present system litigants are subjected to burdensome expense, and the time of courts and juries is unduly occupied with evidence which, in the main, is treated with scant respect.

There are other rules of evidence to which we still cling, although they seem to me to be anachronisms.

"Phillips v. Chater (I882, N. Y. Surro.) I Dem. 533, 545-546.

"Pettit v. Pettit, supra note 9.

${ }^{4}$ See notes 38 and 39 supra. 
Section 828 of the Code of Civil Procedure provides that a person shall not be "excluded or excused from being a witness, by reason of "his or her interest in the event of an action or special proceeding ;" but this is qualified by exceptions contained in sections $829,834,835$, and 836 , which keep in force some of the disqualifications of witnesses based on interest.

By section 829 it is sought to guard against the danger, sometimes very real, of dishonest claims asserted against decedents' estates, by excluding communications made by a decedent to an interested person. This restriction not infrequently works intolerable hardship in preventing the establishment of a meritorious claim. Furthermore, it has been enforced with the most rigorous literalness, and has been the occasion of a labyrinth of subtle decisions. A long experience leads me to believe that the evils guarded against do not justify the retention of the rule. In the early development of our jurisprudence the testimony of all interested witnesses was excluded; but experience gradually led to the conclusion that the restriction should be relaxed and more reliance should be placed upon the efficacy of our process of investigating truth. Cross-examination, for instance, has been found to be well calculated to uncover a fraudulent scheme concocted by an interested party; and where that has failed the scrutiny to which the testimony of a witness is subjected by the court and by the jury, has proven efficacious in discovering the truth, to say nothing of the power of circumstantial evidence to discredit the mere oral statement of an interested witnèss.

Section 834 prohibits a doctor from disclosing "any information "which he acquired in attending a patient, in a professional capacity, "and which was necessary to enable him to act in that capacity," thus in a will contest excluding facts which may be of the most important character. The theory of the section is that information obtained by a doctor is of a confidential character. If the patient is incompetent, however, he is disabled from imposing such professional secrecy; while if he is competent, it ought to be presumed that he would wish to have his physician free to prove that fact. But the section itself is rendered almost absurd in practice by the provisions of section 836 by which the restrictions may be waived by the executors "or the surviving husband, widow or any heir-at-law or any "next of kin, of such deceased, or any other party in interest." Thus, it may happen, and does frequently happen, that a contestant seeking to defeat the purposes of the testator, is able by a waiver to qualify a physician to testify, for the purpose of defeating the expressed wishes of the testator. In a case I recently tried ${ }^{47}$ a contestant who had been on the worst possible terms with the testator, was able to waive the restriction of section 834 , and obtained the evidence of a prejudiced and hostile attending physician, who admitted that he was keenly interested.

"Matter of Spang (Jan. 2I-Mar. 4, Ig20, N. Y. Surro.) not yet reported. 
Section 835 prohibits a lawyer from disclosing a communication made by his client to him in the course of his professional employment. By section 836 , the attorney, if he is a subscribing witness, may testify as to the preparation and execution of the will. But the restriction of section 835 still prevents a lawyer who is not such a witness, from testifying as to the instructions which he received from the testator. Like section 834 it is based upon the confidential character of the professional relation; but it is absurd to imply that the client would wish to have the ban of secrecy so operate as to prevent the establishment of the will which he had employed the lawyer to draw.

The institution of private property is the keystone of the foundation upon which the social, economic, and political structure of Anglo-Saxon civilization is erected. A necessary incident of that institution is the right of an owner of property to transmit it by deed or will to whomsoever he pleases. For many generations this right has been jealously conserved by our courts. But under modern conditions the tendency has increased to subject to meticulous scrutiny the will of a man whose capacity to make a contract or a deed or to perform any other business act, would not be questioned while he was alive; and in the examination of his life history which this involves, our rules of evidence do not permit him to enjoy the vicarious privilege of presenting his side of the case through his natural confidantes,-his beneficiaries, his spiritual adviser, his legal adviser and his physician. Verily it cannot be said of him that "he being dead yet speaketh." Even the aid of legal skill of the highest order cannot give him the consolation that his memory will not be marred by an unseemly disclosure of his foibles and weaknesses. As Lord Brougham said of ex-Chancellors, after Lord Campbell had begun to write their lives, so modern testators may say, that death becomes for them "armed with a new terror;" and if they could speak they would probably in chorus invoke judges and juries as Hamlet did Horatio:

"Horatio, I am dead;

Thou livest; report me and my cause aright

To the unsatisfied." 